\title{
Landscape dynamics of Paspalum quadrifarium grasslands analyzed by Morphological Spatial Pattern Analysis (MSPA)
}

\author{
Marcelo L Gandini ${ }^{\text {Corresp., }}{ }^{1,2}$ ， Bruno D Lara ${ }^{1,3}$, Laura Beatriz Moreno ${ }^{1}$, Maria A Cañibano ${ }^{1}$, Patricia A Gandini \\ 4,5 \\ 1 Facultad de Agronomía, Universidad Nacional del Centro de la Provincia de Buenos Aires, Azul, Buenos Aires, Argentina \\ ${ }^{2} \mathrm{CIC}$ (Comisión de investigaciones Científicas de la provincia de Buenos Aires), Azul, Buenos Aires, Argentina \\ 3 CONICET (Comisión Nacional de investigaciones Científicas y Técnicas de Argentina), Azul, Buenos Aires, Argentina \\ 4 Unidad Académica Caleta Olivia, Universidad Nacional de la Patagonia Austral, Puerto Deseado, Santa Cruz, Argentina \\ 5 CONICET (Comisión Nacional de investigaciones Científicas y Técnicas de Argentina), Puerto Deseado, Santa Cruz, Argentina \\ Corresponding Author: Marcelo L Gandini \\ Email address: mgandini@gmail.com
}

Background. Despite its wide distribution worldwide, only $4.6 \%$ of temperate grasslands are included within systems of protected areas. In Argentina, this situation is even more alarming: only $1.05 \%$ is protected. The study area (central area of the southern Salado River basin) has a large extent of grasslands of Paspalum quadrifarium $(\mathrm{Pq})$ which has been target since the last century of a variety of agricultural management practices including fire burning for cattle grazing.

Methods. Were used as base data bynary images of presence-ausence data of Pq coming from a 42year (1974-2016) land cover change study performed over Landsat Imagery (MSS, TM, ETM, and OLI sensors). MSPA (Morphological Spatial Pattern Analysis) and Network Analysis were performed to the data using Guidos Toolbox for the estimation of habitat and connectivity dynamics of the Pq patches (fragments).

Results. Was observed a loss of area and habitat nuclei of this grassland between the beginning and the end of the study period. A drastic reduction in connectivity was also evident in resulting maps. The number of large Pq grassland fragments ( $>50$ ha) decreased during the study period, and fragmentation measured as number of components (patches) was higher at the end of study period. The Pq pajonal nuclei had their minimum representativeness in 2000, and recovered slightly in 2011, but with a significant percentage increase of the small patches (=islets) and linear elements as bridges and branches. Large corridors (mainly edge of roads) could be observed at the end of study period, while the total connectivity of the landscape pattern drops abruptly.

Discussion. The habitat reduction could have an impact on the ecosystem functioning and the mobility of some species of native fauna. The connecting elements of the landscape were maintained and/or recovered in percentage in 2011 and 2016. This fact, although favoring the dispersion of the present diversity in the habitat nuclei could cause degradation by an edge effect. On the methodological side, the use of a proved tool as Guidos Toolbox for evaluating forest fragmentation could also be useful for monitoring dynamics of a grassland-habitat fragmentation. 


\section{Landscape dynamics of Paspalum quadrifarium grasslands}

\section{2 analyzed by Morphological Spatial Pattern Analysis (MSPA)}

3

\section{Marcelo Luciano Gandini ${ }^{1,3}$ Bruno Daniel Lara ${ }^{1,2}$ Laura Beatriz Moreno ${ }^{1}$ María Alejandra}

\section{Canibano $^{1}$ Patricia Alejandra Gandini ${ }^{2,4}$}

$6 \quad{ }^{1}$ Laboratorio de Investigación y Servicios en Teledetección de Azul (LISTA), Facultad de Agronomía -UNCPBA-

7 Azul, Buenos Aires, Argentina.

$8 \quad{ }^{2}$ CONICET (Comisión Nacional de investigaciones Científicas y Técnicas, Argentina)

$9{ }^{3}$ INAS-CIC (Investigador Asociado Comisión de investigaciones Científicas de la provincia de Buenos Aires,

10 Argentina)

$11{ }^{4}$ UNPA (Universidad Nacional de la Patagonia Austral) Santa Cruz, Argentina

13 Corresponding author:

14 Marcelo Gandini ${ }^{1}$

15 República de Italia 780 (B7300) Azul, Buenos Aires, Argentina

16 Email adress: mgandini@gmail.com 
18 Background. Despite its wide distribution worldwide, only 4.6\% of temperate grasslands are included within systems of protected areas. In Argentina, this situation is even more alarming: only $1.05 \%$ is protected. The study area (central area of the southern Salado River basin) has a large extent of grasslands of Paspalum quadrifarium $(\mathrm{Pq})$ which has been target since the last century of a variety of agricultural management practices including fire burning for cattle grazing.

Methods. Binary images of presence-absence data of Pq from a 42-year (1974-2016) land cover change study were used as base data. MSPA (Morphological Spatial Pattern Analysis) and Network Analysis were performed to the data using Guidos Toolbox for the estimation of habitat and connectivity dynamics of the Pq patches (fragments).

Results. A loss of the coverage area and habitat nuclei of this grassland was observed between the beginning and the end of the study period. A drastic reduction in connectivity was also evident in resulting maps. The number of large Pq grassland fragments ( $>50 \mathrm{ha})$ decreased during the study period, and fragmentation measured as number of components (patches) was higher at the end of study period.

The Pq pajonal nuclei had their minimum representativeness in 2000, and recovered slightly in 2011, but with a significant percentage increase of the small patches (=islets) and linear elements as bridges and branches. Large corridors (mainly edge of roads) could be observed at the end of study period, while the total connectivity of the landscape pattern drops abruptly.

Discussion. The habitat reduction could have an impact on the ecosystem functioning and the mobility of some species of native fauna. The connecting elements of the landscape were maintained and/or recovered in percentage in 2011 and 2016. This fact, although favoring the dispersion of the present diversity in the habitat nuclei could cause degradation by an edge effect. On the methodological side, the use of a proved tool as Guidos Toolbox for evaluating forest fragmentation could also be useful for monitoring dynamics of a grassland-habitat fragmentation.

41

Keywords: Land use, Cattle grazing, Morphology, Connectivity, Paspalum quadrifarium 


\section{INTRODUCTION}

45 The loss of habitat and the fragmentation of ecosystems are one of the main threats to the

46

47 conservation of biodiversity worldwide (Fahrig 2003, Hobbs and Yates 2003, Henle et al 2004, Wilson et al. 2016). In Argentina, the conversion of natural ecosystems to agricultural lands has consequences such as the loss of habitat and biodiversity, the alteration of biotic interactions and biogeochemical processes (water cycles, carbon and nutrients), the reduction of the capacity to provide ecosystem services and the transformation of the landscape (Herrera et al., 2012; Volante et al., 2012; Gandini et al. 2014). In this way, given the magnitude of anthropogenic activities on natural systems (Vitousek et al., 1997), understanding if and how biodiversity recovers from disturbances is an important focus of ecology and conservation biology. Woods et al (2016) emphasized the importance of considering spatial scale while the impacts of a disturbance on an ecosystem are quantified. Across the globe, many once- pristine natural ecosystems have been replaced by human-dominated mosaic landscapes, wherein a patchwork of human land-use patterns has been superimposed on pre-existing patterns of heterogeneity in natural environmental conditions. In such landscapes, species have experienced their environment across a range of spatial scales (Tscharntke et al. 2012), so it is important to evaluate these effects across both time and space (Van Horne 2002).

A characteristic type of grassland landscape in the Salado river basin is the "pajonal" of Paspalum quadrifarium also known as Paspaletum (Vervoorst 1967). It represents one of the twelve plant communities identified for this area and it is a type of grassland characterized by marked abundance of $P$. quadrifarium, a grass that can grow into dense tufts reaching 1 to 1.50 m (Frangi 1986), and various companion species in different proportions. Paspaletum is 
characterized by its distribution in a wide range of topographies (Lara \& Gandini 2013a) forming different vegetation units (Perelman et al. 2003; Lara \& Gandini 2013b).

Pajonal grasslands have been under fire and grazing disturbance for a long time. Since the introduction of domestic livestock by European settlers and almost without interruption, this grassland has been managed changing their coverage and land use in different ways (Foley et al. 2005, Vazquez et al. 2012). Mainly fire is currently used in the winter-spring period with the aim of increasing net productivity and thus livestock receptivity (Laterra 2003). In this way, the interaction of fire with cattle grazing lead to deep changes that can be seen across scales of analysis (Herrera et al 2009; Lara \& Gandini 2011).

Ecologists distinguish between a particular disturbance event -like an individual storm or fireand the disturbance regime that characterizes a landscape (e.g., White and Jentsch 2001).

Disturbance is a "hot topic" in land and resource management and particularly in grassland management, because many disturbance regimes seem to be changing due to human activities, especially climate change. For example, the risk of large fires is increasing in many areas of the world. The disturbance regime refers to the spatial and temporal dynamics over a longer time period and is described by characteristics such as the spatial distribution of disturbances; disturbance frequency, return interval, and rotation period; and disturbance size, intensity, and severity (Turner \& Gardner 2015).

84 Despite its large distribution worldwide, only $4.6 \%$ of temperate grasslands are included within national protected area systems. In Argentina, this situation is even more alarming since only $1.05 \%$ is protected (Bilenca and Miñarro 2004). The underestimation of the productive value of these natural grasslands starts from the difficulty of objectively visualizing the goods and ecosystem services that they provide. 
89 Human encroachment on the environment through resource extraction and urban expansion have

90 led to fragmentation (Maguire et al. 2016), with consequences for biodiversity (Chapin et al.

91 2000), ecosystem processes (Díaz \& Cabido 2001, Harrington et al. 2010) and the ecosystem

92 services that they are supporting (Mitchell et al, 2014).

93 The current increase in agricultural and livestock pressure in the region (Cañibano et al., 2004;

94 Vázquez et al., 2012) pre-supposes a little encouraging scenario due to the replacement of natural

95 pasture coverage. However, Paspaletum (ecological community of Paja Colorada - Paspalum

96 quadrifarium) remnant patches persist in the centre of Buenos Aires province (Herrera et al.,

97 2009). These patches were maintained as pasture sites in good state of conservation according to

98 studies of Fundación Vida Silvestre Argentina (Bilenca and Miñarro 2004). So, these sites were

99 classified as Valuable Grassland Areas (PVAs), given their importance as a source of great

100 native animal diversity and the numerous ecosystem services they provide.

101 Fahrig (2003) considered fragmentation as one of the most damaging threats to biodiversity

102 conservation in recent times because the population viability in fragmented landscapes depends

103 to a large extent on the structural and functional integrity of the landscape. In this context, it is

104 necessary to carry out studies that allow analysing the trends of change in these habitat fragments

105 and their connections to implement management and conservation strategies in areas of high

106 regional ecological importance.

107 The sustainable management of fragmented landscapes will depend on understanding the spatial

108 ecology of the ecosystem services needed over the long-term (Maguire et al. 2016). In terms of

109 functional integrity of ecosystems, landscape connectivity is considered one of the key properties

110 to maintain biodiversity. Landscape connectivity is defined as the degree to which landscape

111 facilitates the movement of species and other ecological flows (Taylor et al., 1993). It is 
112 considered a key aspect to take in account for biodiversity conservation efforts around the world

113 and one of the best responses to counteract the negative effects of habitat fragmentation and to

114 facilitate species adaptation to changes in their natural habitats (Crooks and Sanjayan 2006).

115 Morphological Spatial Pattern Analysis (MSPA) has been promoted in the last decade by the

116 Joint Research Center of the European Commission (JRC) to contribute to the knowledge and

117 exchange of information on issues related to ecosystem patterns of disturbance in human-

118 managed ecosystems, assessing fragmentation and connectivity in Europe and in the world.

119 MSPA is described by Vogt et al. (2007a) as "a customized sequence of mathematical

120 morphological operators to describe the geometry and connectivity of the components of an

121 image."

122 MSPA approach uses a binary method of image classification based on the geometry and forms

123 of the elements to classify the patterns into seven categories: core, islet, loop, bridge, perforation,

124 edge, and branch (Soille \& Vogt, 2008). MSPA approach has been applied in landscape ecology

125 to identify and map the structural patterns of forests at pixel level, allowing identification of

126 fragmentation issues (Vogt et al., 2007a) and the connective elements of a landscape as the

127 corridors (Vogt et al., 2007b). MSPA also has been implemented to analyse the connectivity of

128 forests in Europe through the identification of key structural elements that play the role of

129 connectors and the integration of connectivity indexes based on habitat availability (Saura et al.,

130 2011). Other structural elements such as riparian corridors have been identified through the

131 MSPA approach to study their contribution to structural connectivity and to establish

132 conservation valuation criteria (Clerici and Vogt, 2013). Likewise, the US green infrastructure

133 has been morphologically classified and mapped to know its distribution with a view to forest

134 protection and correct decision-making in landscape planning (Wickham et al., 2010). This 
135 approach was used to identify and classify the morphological types of fragmentation, based on

136 the availability of habitat and to recognize the temporal variation between the elements that

137 contribute to the maintenance of landscape connectivity.

138 Improved landscape connectivity is increasingly considered a viable management strategy to

139 maintain biodiversity, ecosystem functions, and services (Ziter et al. 2013). In a part of the study

140 area -the Salado River basin- the habitat fragmentation pattern has been reported to have

141 increased considerably in the last 40 years (Lara \& Gandini 2014), Thus becoming one of the

142 major environmental problems in the basin. In this way, this research presents a novel

143 application of the MSPA approach in the monitoring of change over time in the fragments of

144 grassland, the Paspalum quadrifarium habitats.

145 In this work the MSPA was applied to a remote sensing classification of Landsat images in order

146 to analyze the 40-year temporal change in the habitat fragments of the "pajonal" grasslands

147 (Paspalum quadrifarium).

148 MATERIALS \& METHODS

149 Study Area

150 The study was carried out in the Flooding Pampa and Inland Pampa areas of the Salado River

151 basin, in the Buenos Aires province (Argentina), covering mainly two different agroecological

152 zones, the "Flooding and Inland Pampas" (Figure 1), which concentrates the greatest

153 representativeness of the ecological community of interest (Gandini et al., 2014).

154 Data acquisition, pre-processing and land cover classification

155 A series of five Landsat images (path 225, row 85) for the years 1974 (MSS sensor), 1988 (TM

156 sensor), 2000 (ETM + sensor), 2011 (TM sensor) and 2016 (OLI sensor) was used. The digital

157 numbers (DN) were converted to reflectance (except the thermal band) according to Chander et 
158 al. (2009), and the reflectance values were then adjusted for atmospheric scattering using the

159 Improved Dark Object Subtraction method by Chavez (1996).

160 In accordance with previous reports (Herrera et al., 2009, Lara and Gandini, 2013b), the initial

161 land cover types used were: pajonal, short-grass matrix, pastures, crops and water bodies. To

162 identify the land cover types, supervised classifications were employed using the maximum

163 likelihood algorithm (Lu and Weng 2007). The classifications were performed using all

164 reflective Landsat bands; for 1974: MSS4, MSS5, MSS6 and MSS7; for 1988 and 2011: TM1,

$165 \mathrm{TM} 2, \mathrm{TM} 3, \mathrm{TM} 4, \mathrm{TM} 5$ and TM7; for 2000: $\mathrm{ETM}+1, \mathrm{ETM}+2, \mathrm{ETM}+3, \mathrm{ETM}+4, \mathrm{ETM}+5$

166 and ETM + 7, and for 2016, Bands 2, 3, 4, 5, 6 of OLI Sensor. The thermal bands of platforms

167 were discarded.

168 For 1988, the training sites were located by visual interpretation on 44 aerial infra-red

169 photographs (scale 1: 20,000) taken in 1988 summer, following criteria such as texture, shape

170 and colour (Chuvieco,2010). For 2011 and 2016, the control points were selected using a global

171 positioning system (GPS) in the field within relatively homogeneous areas. For 1974 and 2000,

172 the training sites were selected by visual analysis following the medium spectral signature for

173 each land cover type and using areas with similar spectral characteristics - over land cover

174 remained unchanged- (Chuvieco, 2010; Schulz et al., 2010).

175 Classification results were filtered using a 7 × 7 median filter to remove isolated pixels. Later,

176 the MSS classification (1974) was re-sampled to a $30 \times 30 \mathrm{~m}$ pixel size to allow multi-temporal

177 comparison with the rest of the series.

178 The accuracy of the classification maps was assessed with the use of quantity disagreement and

179 allocation disagreement (Pontius and Millones, 2011). These indexes are more useful and

180 simpler than standard Kappa (Congalton, 1991) and allow us to focus on two components of 
181 disagreement between maps and reference points in terms of the quantity and spatial allocation

182 of the land cover types.

183 Pajonal fragments were identified based on these classifications, and binary Pajonal presence-

184 absence maps were created. These binary maps of 1974, 1988, 2000, 2011 and 2016 were

185 analyzed using a morphological classification (MSPA) with the software Guidos Toolbox (Soille

186 and Vogt, 2008; Vogt, 2014).

187 A comparative analysis of landscape connectivity was carried out, evaluating the variations in

188 the size and connectivity of the patches of pajonal. The analysis was performed considering each

189 set of connected patches as a single landscape element. In this way the size of the elements

190 varied as the patches were fragmented and disconnected by the effect of the livestock

191 management (fire and grazing disturbance).

192 In addition ECA was calculated. ECA is defined as the size of a single habitat patch (maximally

193 connected) that would provide the same value of the probability of connectivity than the actual

194 habitat pattern in the landscape. It is calculated as the square root of the numerator of the PC

195 index (Saura et al. 2011).

196

197 RESULTS AND DISCUSSION

198 A complete set of resulting images of Classification, MSPA and connectivity for a set of 5

199 analyzed years is stored in supplementary material that could be opened by free software as

200 QGIS (2018) and similar, as well as Guidos Toolbox (Vogt 2014) .txt outputs for seeing running

201 details. For reasons of simplicity of interpretation only maps of extreme years in time (1974-

202 2016) are shown in the main body of text.

203 Image classification of land cover 
204 Classification error issues are shown in Table 1. Good thematic accuracies for Pq were obtained,

205 and the separation of overall disagreement into two components was used to learn about sources

206 of error and give guidance on how to improve each classification (Pontius and Millones, 2011).

207 Quantity disagreements, and not allocation disagreement, were particularly taken into

208 consideration to assess classification quality since the main aim of this work was focused on

209 regional changes and not pixel-to-pixel changes (Keller and Smith 2014)

\section{Fragmentation and habitat loss}

211 The observation of the MSPA image product (Fig. 2) indicates a loss of area of grassland as a

212 whole, and of the habitat nuclei between the beginning and the end of the study period. A drastic

213 reduction in connectivity is also evident. The number of large pajonal fragments ( $>50 \mathrm{ha}$ )

214 decreased during the study period, but the greatest fall was observed in 2000, although in 2011

215 this trend continued at a lower rate (Table 1).

216 Fragmentation measured as number of components (patches) resulting from habitat pressure is

217 higher in 2011 and 2016 (Table 1). This observation agrees with MSPA data, in which the

218 pajonal nuclei had their minimum representativeness in 2000 , and recovered by 2011 , with a

219 significant percentage increase in the small patches (=islets). While edges and curls remained

220 relatively stable, the linear elements (bridges and branches) increased their representativeness

221 (Table 1, MSPA; see also Figure 2). This fact, although favoring the dispersion of the present

222 diversity in the habitat nuclei could cause degradation by an edge effect. The connecting

223 elements of the landscape were maintained and/or recovered in percentage. Larger corridors

224 (mainly edge of roads) could be observed while the total connectivity of the landscape pattern

225 drops abruptly (Table 1, connectivity and Figure 2) in terms of mean and median connectivity

226 after 1988 and \%ECA after 2011. 
227 The effect on diversity could be more important when considering that habitat patches form a

228 "network" and that they are not connected to each other (Maguire et al. 2016). This loss of

229 connectivity is clearly evidenced in Figure 3.

230 Temporal variation of ECA\% shows the dynamics of the fragmentation process in the study

231 area: from a value of 28 , doubling the patch size in 1988 is necessary to reach similar

232 connectivity (median values). In successive years, the connectivity and ECA decline to a

233 minimum in 2011, showing a slight recovery in 2016.

234 Within the frame of environmental conservation issues, monitoring these environments and

235 conducting further research on their impact on biodiversity are deemed necessary. In this work,

236 as Wickham et al. (2010) this approach was used to identify and classify the morphological types

237 of fragmentation, focusing on the dynamics of habitat availability, and to recognize the variation

238 in the time of the connective elements of the landscape.

239 In this research it is noticeable a high and sustained habitat decline in the period 1974-2011 and a

240 slight recovery (in some indicators) in 2016. Monitoring the dynamics of these grasslands is

241 necessary to contribute to their conservation.

242 This research opens up the need to think about a short-term research on the minimum size of

243 pajonal fragments that preserve ecosystem services, and maintain in an acceptable status their

244 biodiversity components and structure.

\section{CONCLUSIONS}

247 The variations in the size and connectivity of the patches of Pq were significant in the study 248 period (1974-2016). the major effects were the habitat fragmentation and patch size reduction

249 leading to connectivity loss. In terms of fragmentation, there was a true fragmentation, and also 
250 habitat loss, determined by a high trend to lower the patch size and connectivity. Slight structural

251 recovery in terms of area could be seen at the end of the study period (2016). This trend is clearer

252 in connectivity issues measured by ECA\%.

253 This work showed that the habitat patches of Pq, have undergone deep transformations since

2541974 interchanging the original landscape matrix by other subordinate community, the Short-

255 Grasses Matrix (Lara \& Gandini 2014). These changes could be evidenced through the

256 application of a methodology originally used for the study of forest fragmentation, the

257 morphology and connectivity analysis (Vogt et al 2007a).

258

\section{BIBLIOGRAPHY}

260 Bilenca D. y F. Miñarro. 2004. Identificación de áreas valiosas de pastizal (AVPs) en las pampas

261 y campos de Argentina, Uruguay y sur de Brasil. 1a. ed. Fundación Vida Silvestre. Buenos

262 Aires, Argentina.

263 Cañibano M.A., M. Gandini y M. Sacido. 2004. Evaluación de la intensificación del uso de la

264 tierra, en la cuenca del Arroyo del Azul, Buenos Aires, Argentina. Proceedings XI Simposio

265 Latinoamericano de percepción remota. Santiago, Chile.

266 Chander, G. B., Markham, L. and Helder, D.L. (2009): Summary of current radiometric

267 calibration coefficients for Landsat MSS, TM, ETM+, and EO-1 ALI sensors. Remote Sensing

268 of Environment, 113, 893-903. DOI: 10.1016/j.rse.2009.01.007

269 Chapin FS, Zavaleta ES, Eviner VT, Naylor RL, Vitousek PM, Reynolds HL, et al. 2000.

270 Consequences of changing biodiversity. Nature. 405:234-242. DOI: 10.1038/35012241

271 Chavez, Jr. P. 1996: Image-based atmospheric correction- Revisited and improved

272 Photogrammetric Engineering and Remote Sensing, 2 (9), 1025-1036. 
273 Chuvieco, E. 2010. Teledetección ambiental. Madrid, Editorial Ariel.

274 Clerici, N. \& Vogt P. 2013. Ranking European regions as providers of structural riparian

275 corridors for conservation and management purposes. International Journal of Applied Earth

276 Observation and Geoinformation 21(0): 477-483. DOI: 10.1016/j.jag.2012.07.001

277 Congalton, R. G. 1991: A review of assessing the accuracy of classifications of remotely sensed

278 data. Remote Sensing of Environment, 37, 35-46. DOI: 10.1016/0034-4257(91)90048-B

279 Crooks, K. R. y Sanjayan, M. 2006. Connectivity conservation. Cambridge Univ. Press. DOI:

$280 \quad 10.1017 / \mathrm{CBO} 9780511754821$

281 Díaz S, Cabido M. 2001. Vive la différence: plant functional diversity matters to ecosystem

282 processes. Trends in Ecology and Evolution 16:646-655.4. DOI: 10.1016/S0169-

$283 \quad 5347(01) 02283-2$

284 Fahrig L. 2003. Effects of habitat fragmentation on biodiversity. Annual Review of Ecology

285 Evolution and Systematics 34:487-515. DOI: 10.1146/annurev.ecolsys.34.011802.132419

286 Foley JA, Defries R, Asner GP, Barford C, Bonan G, Carpenter SR Chapin FS, Coe MT, Daily

287 GC, Gibbs HK, Helkowski JH, Holloway T, Howard EA, Kucharik CJ, Monfreda C, Patz JA,

288 Prentice IC, Ramankutty N, Snyder PK. 2005. Global consequences of land use. Science

289 309:570-574 DOI: 10.1126/science.1111772

290 Frangi, J. 1986. Sinopsis de las comunidades vegetales y el medio de las Sierras de Tandil.

291 Boletín de la Sociedad Argentina de Botánica (Argentina) 16(4): 293-319.

292 Gandini M., Lara B. y Scaramuzzino R. 2014. Zonificación basada en la respuesta de

293 ecosistemas a oscilaciones climáticas. Revista estudios Ambientales (Argentina) Vol 2:2 4-24.

294 Harrington, R.; Dawson, T.P; de Bello, F.; Feld, C.K.; Haslett, J.R.; Kluvánkova-Oravská, T.;

295 Kontogianni, A.; Lavorel, S.; Luck, G.W.; Rounsevell, M.D.A.; Samways, M.J.; Skourtos, M.; 
296 Settele, J.; Spangenberg, J.H.; Vandewalle, M.; Zobel, M. and P.A. Harrison. 2010. Ecosystem

297 services and biodiversity conservation: concepts and a glossary. Biodiversity and Conservation

298 19: 2773-2790. DOI: 10.1007/s10531-010-9834-9

299 Henle, K., Lindenmayer, D.B., Margules, C.R. Saunders D.A., Wissel C. 2004. Species Survival

300 in Fragmented Landscapes: Where are We Now? Biodiversity and Conservation13:1. DOI:

301 10.1023/B:BIOC.0000004311.04226.29

302 Herrera L., P. Laterra, N. Maceira, K. Zelaya y G. Martínez. 2009. Fragmentation status of tall-

303 tussock grassland relicts in the Flooding Pampa, Argentina. Rangeland Ecology and

304 Management 62: 73-82. DOI: 10.2111/08-015

305 Herrera, L.P. M. Texeira \& J.M. Paruelo 2012 Fragment size, vegetation structure and physical

306 environment control grassland functioning: a test based on artificial neural networks. Applied

307 Vegetation Science DOI: 10.1111/avsc.12009

308 Hobbs, R. J. \& Yates, C.J. (2003). Turner Review $\mathrm{N}^{\circ} 7$ - Impacts of ecosystem fragmentation on

309 plant populations: generalising the idiosyncratic. CSIRO Publishing, 2003.

310 oai:researchrepository.murdoch.edu.au: 16780

311 Keller J.K. and C.R. Smith, Improving GIS-based Wildlife-Habitat Analysis, Springer Briefs in

312 Ecology, DOI: 10.1007/978-3-319-09608-7

313 Lara B. \& M. Gandini. 2011. Biogeografía de islas en fragmentos de pajonal del Paisaje Ariel

314 (Azul, Buenos Aires, Argentina). Revista Asociación Argentina de Ecología de Paisajes 2: 1-8.

315 Lara, B \& M Gandini. 2013a. Nuevo aporte para la distribución del Paspaletum en el centro de la

316 provincia de Buenos Aires. Revista Asociación Argentina de Ecología de Paisajes 4:1-12.

317 Lara B. \& M. Gandini. 2013b. Subdivisión de paisajes basada en aspectos funcionales de la

318 Pampa Deprimida. Revista de la Facultad de Agronomía UNL-Pam 22(Supl.2): 93-98. 
319 Lara, B. \& Gandini, M. 2014. Quantifying the land cover changes and fragmentation patterns in

320 the Argentina Pampas, in the last 37 years (1974-2011). GeoFocus (Artículos), 14:163-180.

321 Laterra P. 2003. Desde el Paspaletum: bases ecológicas para el manejo de pajonales húmedos

322 con quemas prescriptas. En: Fuego en los ecosistemas argentinos (C.R. Kunt, S. Bravo \& J.L.

323 Panigatti eds.).Ediciones INTA, Santiago del Estero, Argentina.

324 Lu, D., Weng, Q., 2007. A survey of image classification methods and techniques for

325 improving classification performance. International Journal of Remote Sensing 26 (5), 823-870.

326 DOI: $10.1080 / 01431160600746456$

327 Maguire DY, Buddle CM, Bennett EM (2016) Within and Among Patch Variability in Patterns

328 of Insect Herbivory Across a Fragmented Forest Landscape. PLoS ONE 11(3): e0150843. DOI:

329 10.1371/journal.pone.0150843

330 Mitchell MGE, Bennett EM, Gonzalez A. 2014. Forest fragments modulate the provision of

331 multiple ecosystem services. Journal of Applied Ecology; 51:909-918 DOI: 10.1111/1365-

$332 \quad 2664.12241$

333 Perelman, S; S Burkart \& C León. 2003. The role of a native tussock grass (Paspalum

334 quadrifarium Lam.) in structuring plant communities in the Flooding Pampa grasslands,

335 Argentina. Biodiversity and Conservation 12: 225-238. DOI: 10.1023/A:1021948723714

336 Pontius, R. G. and M. Millones (2011): "Death to Kappa: birth of quantity disagreement and

337 allocation disagreement for accuracy assessment”, Intl Journal of Remote Sensing, 32 (15),

338 4407-4429. DOI: 10.1080/01431161.2011.552923

339 QGIS Development Team. 2018. QGIS Geographic Information System. Open Source

340 Geospatial Foundation Project. Website: http://qgis.osgeo.org 
341 Saura S, Vogt P, Velázquez J, Hernando A, Tejera R. 2011. Key structural forest connectors can

342 be identified by combining landscape spatial pattern and network analyses. Forest Ecology and

343 Management 262 (2011) 150-160. DOI: 10.1016/j.foreco.2011.03.017

344 Schulz, J. J., L. Cayuela, C. Echeverría, J. Salas and J. M. Rey Benayas 2010. Monitoring land

345 cover change of the dryland forest landscape of Central Chile (1976-2008) Applied Geography

34630 436-447. DOI: 10.1016/j.apgeog.2009.12.003

347 Soille P. \& Vogt P. 2008. Morphological segmentation of binary patterns. Pattern Recognition

348 Letters 30, 4:456-459 DOI: 10.1016/j.patrec.2008.10.015

349 Turner M.G, and R.H. Gardner, 2015 Landscape Ecology in Theory and Practice, Springer-

350 Verlag New York DOI: 10.1007/978-1-4939-2794-4_6.

351 Taylor, P. D., L. Fahrig, K. Henein, and G. Merriam. 1993. Connectivity is a vital element of 352 landscape structure. Oikos 68:571-573.

353 Tscharntke T, Tylianakis JM, Rand TA, Didham RK, Fahrig L, Batáry P, Bengtsson J, Clough

354 Y, Crist TO, Dormann CF, Ewers RM, Fründ J, Holt RD, Holzschuh A, Klein AM, Kleijn D,

355 Kremen C, Landis DA, Laurance W, Lindenmayer D, Scherber C, Sodhi N, Steffan-Dewenter I,

356 Thies C, van der Putten WH, Westphal C. 2012 Landscape moderation of biodiversity patterns

357 and processes - eight hypotheses. Biological Reviews of the Cambridge Philosophical Society.

358 87(3):661-85. DOI: 10.1111/j.1469-185X.2011.00216.x

359 Vazquez P., L. Zulaica y E. Requesens. 2012. Análisis del proceso de agriculturización en el

360 partido de Azul (provincia de Buenos Aires), mediante el uso de sensores remotos (1984-2011).

361 Actas del Congreso Argentino de Teledetección. Córdoba, Argentina.

362 Van Horne, B. 2002. Approaches to habitat modeling: The tensions between pattern and process

363 and between specificity and generality. pp 63-72 in: Predicting Species Occurrences: Issues of 
364 Accuracy and Scale (J.M. Scott, P.J. Heglund, and M.L. Morrison, Eds.). Island

365 Press, Washington, DC.

366 Vervoorst, FB. 1967. Las comunidades vegetales de la Depresión del Salado (Provincia de

367 Buenos Aires). La vegetación de la República Argentina. Serie Fitogeográfica 7, INTA. Buenos

368 Aires, $262 \mathrm{pp}$.

369 Vitousek P. M., H. A. Mooney; J. Lubchenco; J. M. Melillo, 1997. Human Domination of Earth's

370 Ecosystems. Science New Series, Vol. 277, N 5325 pp. 494-499. DOI:

$3710.1126 /$ science.277.5325.494/

372 Vogt, P., Riitters, K.H., Estreguil, C. et al. 2007a. Mapping Spatial Patterns with Morphological

373 Image Processing. Landscape Ecology 22: 171. 10.1007/s10980-006-9013-2

374 Vogt, P, Riitters, K, Iwanowski, M, Estreguil, C, Kozak, J, Soille, P. 2007b. Mapping landscape

375 corridors. Ecological Indicators. 7. 481-488. DOI: 10.1016/j.ecolind.2006.11.001/

376 Vogt P, 2014. GuidosToolbox (Graphical User Interface for the Description of Image Objects

377 and their Shapes): Digital image analysis software collection available online:

378 http://forest.jrc.ec.europa.eu/download/software/guidos

379 Volante, J.N. D. Alcaraz-Segura, M.J. Mosciaro, E.F. Viglizzo, J.M. Paruelo, 2012. Ecosystem

380 functional changes associated with land clearing in NW Argentina,Agriculture, Ecosystems \&

381 Environment, Volume 154:12-22, DOI: 10.1016/j.agee.2011.08.012

382 White PS, Jentsch A (2001) The search for generality in studies of disturbance and ecosystem

383 dynamics. Progress in Botany 62:399-450

384 Wickham, J D, Riitters KH, Wade T G, Vogt P, 2010. A national assessment of green

385 infrastructure and change for the conterminous United States using morphological image 
386 processing. Landscape and Urban Planning 94, 186-195. DOI:

387 10.1016/j.landurbplan.2009.10.003

388 Wilson, M.C., Chen, XY., Corlett, R.T. et al. 2016 Habitat fragmentation and biodiversity

389 conservation: key findings and future challenges. Landscape Ecology (2016) 31: 219. DOI:

$390 \quad 10.1007 / \mathrm{s} 10980-015-0312-3$

391 Woods LM, Biro EG, Yang M, Smith KG. (2016) Does regional diversity recover after

392 disturbance? A field experiment in constructed ponds. PeerJ 4:e2455 DOI: 10.7717/peerj.2455/

393 Ziter C, Bennett EM, Gonzalez A. 2013. Functional diversity and management mediate

394 aboveground carbon stocks in small forest fragments. Ecosphere. 4: art85.6 DOI:10.1890/ES13-

$395 \quad 00135.1 /$

396 


\section{Table $\mathbf{1}$ (on next page)}

Classification Quality of Pq cover estimation, and numerical results of the morphological and connectivity analysis.

Most significant MSPA results (as percentages over the total) and connectivity analysis:

Number of components, maximum, mean and median of connectors / component; and relative ECA 
1

\begin{tabular}{lllllll} 
Analysis & Parm/Form/year & 1975 & 1988 & 2000 & 2011 & 2016 \\
\hline Class. Disagreement \% (PJ) & Quantity & 1 & 5 & 5 & 4 & 2 \\
& Allocation & 10 & 18 & 12 & 9 & 12 \\
\hline MSPA & Core (small) & 4,35 & 3,12 & 3,68 & 3,17 & 3,46 \\
& Core (medium) & 4,65 & 2,08 & 3,12 & 2,85 & 2,17 \\
& Core (large) & 11,94 & 4,58 & 6,06 & 3,73 & 3,71 \\
& Islet & 1,05 & 2,53 & 1,11 & 1,46 & 1,75 \\
& Perforation & 1,72 & 0,62 & 0,56 & 0,28 & 0,50 \\
& Edge & 13,52 & 6,87 & 9,07 & 7,36 & 8,65 \\
& Loop & 1,08 & 0,89 & 0,69 & 0,32 & 0,65 \\
& Bridge & 3,23 & 4,85 & 2,80 & 1,82 & 2,46 \\
& Branch & 2,43 & 3,24 & 2,35 & 2,13 & 2,31 \\
\hline Components & \# total & 2726 & 2061 & 2186 & 2852 & 3772 \\
\hline Conectivity & Mean of links & 1153 & 379 & 287 & 167 & 49 \\
(links) & median of links & 55 & 49 & 41 & 21 & 43 \\
& max links & 80557 & 28468 & 16738 & 15040 & 43912 \\
& ECA (pixels) & 945277 & 894122 & 1041192 & 236552 & 374184 \\
& relative ECA \% & 28 & 57 & 50 & 15 & 25
\end{tabular}

2 


\section{Figure 1}

Study area and Agroecological zones

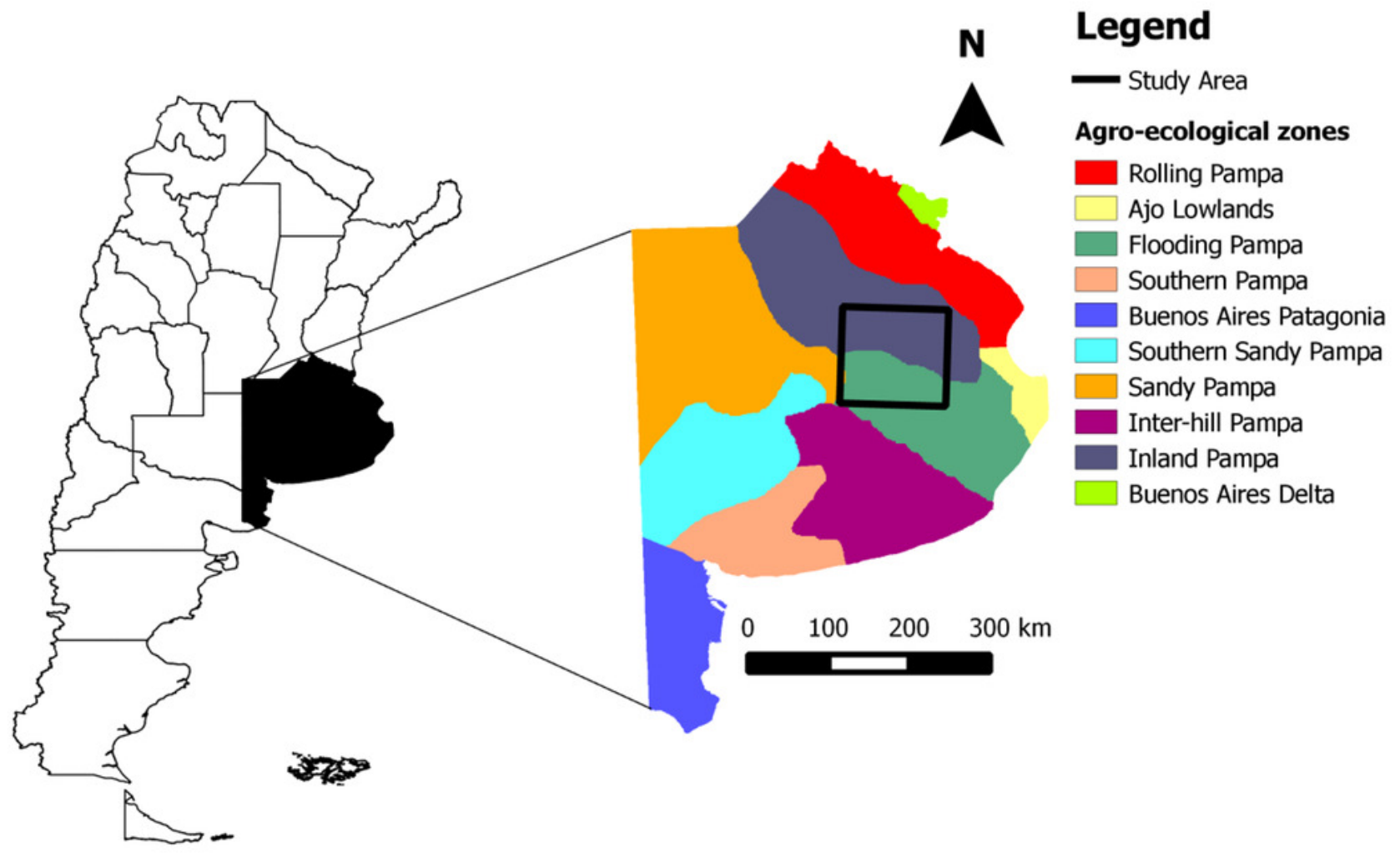




\section{Figure 2}

Map of MSPA segmentation results of Paspalum quadrifarium presence-absence data (1974 vs. 2016)

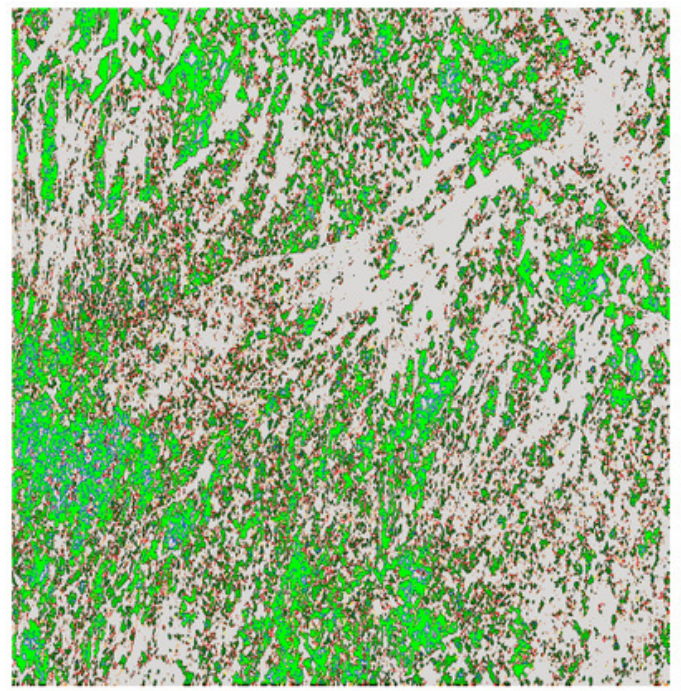

1974

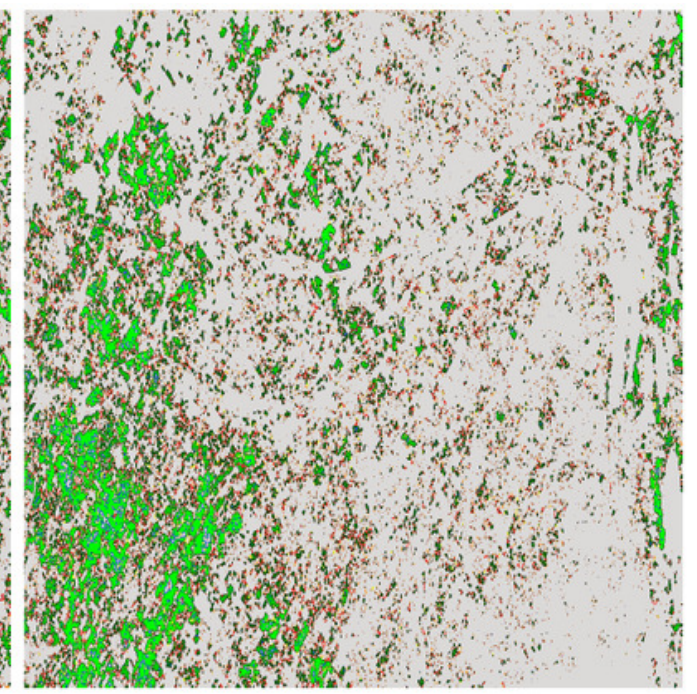

2016
References

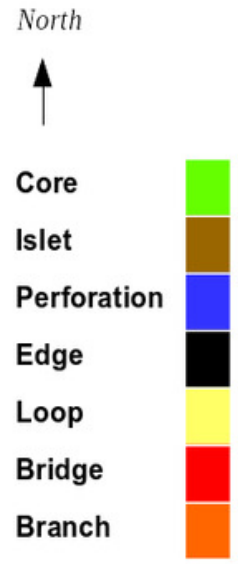


Figure 3

A visual comparison between 1974 and 2016 connectivity results

Different colors indicate patches belonging to different networks

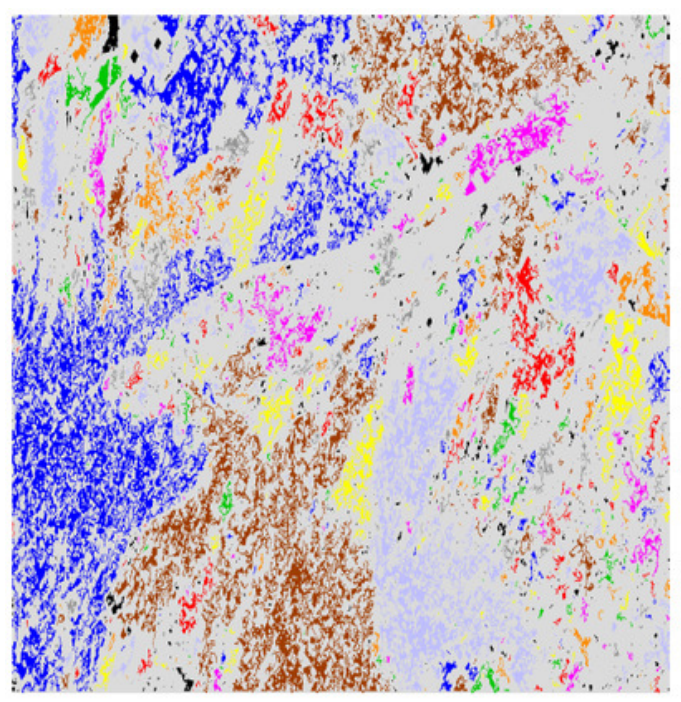

1974

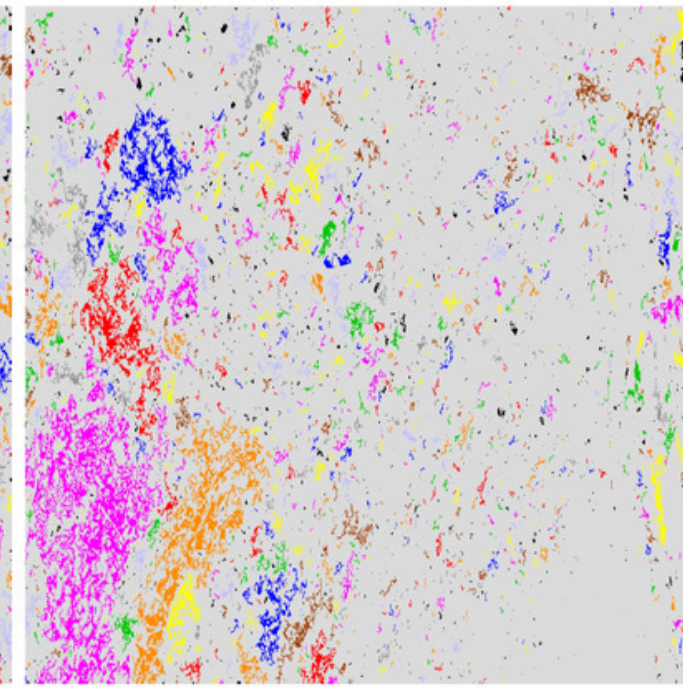

2016 